\title{
Ten years of clinical experience with biosimilar human growth hormone: a review of safety data
}

\author{
This article was published in the following Dove Press journal: \\ Drug Design, Development and Therapy \\ 16 May 2017 \\ Number of times this article has been viewed
}

\author{
Maria Victoria Borrás \\ Pérez' \\ Berit Kriström² \\ Tomasz Romer ${ }^{3}$ \\ Mieczyslaw Walczak ${ }^{4}$ \\ Nadja Höbel ${ }^{5}$ \\ Markus Zabransky ${ }^{5}$ \\ 'Hospital General de Granollers, \\ Granollers, Barcelona, Spain; \\ ${ }^{2}$ Department of Clinical Sciences, \\ Pediatrics, Umeå University, \\ Umeå, Sweden; ${ }^{3}$ Department of \\ Endocrinology, Children's Health \\ Research Institute, Warsaw, \\ ${ }^{4}$ Department of Paediatric \\ Endocrinology and Diabetology, \\ Pomeranian Medical University, \\ Szczecin, Poland; ${ }^{5}$ Sandoz \\ Biopharmaceuticals, Hexal AG, \\ Holzkirchen, Germany
}

\begin{abstract}
Safety concerns for recombinant human growth hormone (rhGH) treatments include impact on cancer risk, impact on glucose homeostasis, and the formation of antibodies to endogenous/exogenous GH. Omnitrope ${ }^{\circledR}$ (biosimilar rhGH) was approved by the European Medicines Agency in 2006, with approval granted on the basis of comparable quality, safety, and efficacy to the reference medicine $\left(\right.$ Genotropin $\left.^{\circledR}\right)$. Additional concerns that may exist in relation to biosimilar rhGH include safety in indications granted on the basis of extrapolation and the impact of changing to biosimilar rhGH from other rhGH treatments. A substantial data set is available to fully understand the safety profile of biosimilar rhGH, which includes data from its clinical development studies and 10 years of post-approval experience. As of June 2016, $106,941,419$ patient days (292,790 patient-years) experience has been gathered for biosimilar rhGH. Based on the available data, there have been no unexpected or unique adverse events related to biosimilar rhGH treatment. There is no increased risk of cancer, adverse glucose homeostasis, or immunogenic response with biosimilar rhGH compared with the reference medicine and other rhGH products. The immunogenicity of biosimilar rhGH is also similar to that of the reference and other rhGH products. Physicians should be reassured that rhGH products have a good safety record when used for approved indications and at recommended doses, and that the safety profile of biosimilar rhGH is in keeping with that of other rhGH products.
\end{abstract}

Keywords: recombinant human growth hormone, Omnitrope ${ }^{\mathbb{R}}$, biosimilar

\section{Introduction}

Recombinant human growth hormones (rhGH) have been in clinical use for three decades. ${ }^{1}$ During this time, the safety of rhGH in children and adults has received considerable attention. ${ }^{2}$ A recent appraisal of $\mathrm{rhGH}$ in children and adults concluded that rhGH continues to have a good safety record when used for approved indications and at recommended doses, while noting the need for continued surveillance of those exposed to these therapies. ${ }^{2}$ Another recent study assessed expected deaths in Swedish patients $(n=3,847)$ treated in childhood with rhGH for idiopathic isolated GH deficiency, idiopathic short stature, or born small for gestational age (SGA). ${ }^{3}$ Compared with the general Swedish population, the ratio of observed/expected deaths was not increased in the childhood rhGH-treated group when adjusting for birth characteristics.

Safety concerns for rhGH treatments generally include impact on cancer risk, impact on glucose homeostasis, and the formation of antibodies to endogenous/exogenous $\mathrm{GH}^{4,5}$ Additional concerns that may exist in relation to Omnitrope ${ }^{\circledR}$ (biosimilar rhGH; Sandoz, Kundl, Austria) and its biosimilar status include safety in indications granted on the basis of extrapolation and the impact of changing to a biosimilar rhGH from other rhGH treatments. This article reviews the safety experience gained with biosimilar rhGH during 10 years of clinical use. By 2015, 42,300 patients worldwide had been treated with biosimilar rhGH;
Correspondence: Markus Zabransky Sandoz Biopharmaceuticals, Hexal AG, Industriestrasse 25, D-83607

Holzkirchen, Germany

Tel +498024 4762255

Fax +498024 4762262

Email markus.zabransky@sandoz.com

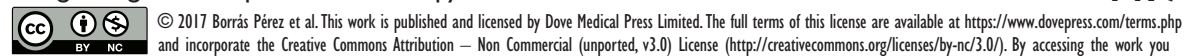

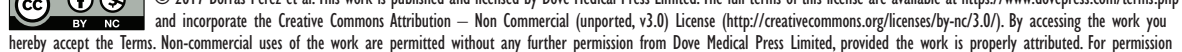

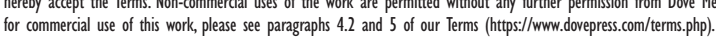


as of June $2016,106,941,419$ patient days $(292,790$ patientyears) experience had been gathered for this product. Physicians should be reassured that the safety profile of biosimilar rhGH is in keeping with that of other rhGH products.

\section{Safety profile in phase III studies}

The phase III clinical development program for biosimilar rhGH included three pivotal studies and a total of 210 children with growth failure secondary to growth hormone deficiency (GHD; Table 1). The AQ study was a multicenter, randomized, controlled, open-label phase III study consisting of three parts, performed consecutively in the same cohort of children with GHD ( $n=89) .{ }^{6,7}$ Throughout the 84 months of treatment, the safety profile of biosimilar rhGH was as expected from previous experience with the reference medicine and other rhGH preparations. The majority of reported adverse events (AEs) were mild in intensity. Adverse drug reactions (ADRs) with a frequency of at least 0.05 events per patient-year included increased glycosylated hemoglobin (HbAlc), headache, and injection-site hematoma. Only one serious adverse reaction was reported; this was a case of worsening of pre-existing scoliosis that required several hospitalizations during the study period.

The Lyo study was a multicenter, non-comparative phase III study using biosimilar rhGH $5 \mathrm{mg} / \mathrm{mL}$ lyophilized formulation in the treatment of GHD children $(n=51){ }^{6}$ Children were treated for a period of up to 48 months. The biosimilar rhGH safety profile was as expected from previous experience with the reference medicine and other rhGH preparations. AEs occurring in $>5 \%$ of patients were eosinophilia (12\%), injection-site reactions $(10 \%)$, hypothyroidism $(8 \%)$, and scoliosis $(6 \%)$. The majority of AEs were mild in intensity; three (contusion, increase in blood alkaline phosphatase, and increase in $\mathrm{HbA1}$ ) were assessed as being of moderate intensity. No patients withdrew from study treatment due to an $\mathrm{AE}$, and there were no drug-related serious AEs.
The third phase III study was an open-label study conducted in Spain to assess the safety and efficacy of long-term treatment (up to 5 years) with biosimilar rhGH $3.3 \mathrm{mg} / \mathrm{mL}$ liquid formulation in children with GHD $(\mathrm{n}=70){ }^{8}$ The majority of reported AEs (401/426; 94\%) were assessed as mild in intensity; 22 were assessed as moderate and one (toothache) as severe. Drug-related AEs (17 events) were reported in 10 patients; $15 / 17$ were assessed as mild in intensity. Drug-related AEs included myopia (1), vomiting (2), gastroenteritis (1), viral pharyngitis (1), injection-site pain (2), antibody test abnormal (3), hyperglycemia (1), tendonitis (1), headache (2), migraine (2), and dermatitis (1). No patients withdrew from study treatment due to an $\mathrm{AE}$, and there were no drug-related serious AEs. ${ }^{8}$ At the end of the study, those patients still growing were offered to remain on treatment (as in usual clinical practice) and continued to be monitored for up to a further 5 years. ${ }^{9}$ No treatment-related AEs were reported in any of the patients who participated in the additional treatment and follow-up period. None of the patients discontinued this part of the study due to an AE.

A phase IIIb study was also conducted, in France, in 51 patients with GHD (Data on file, Sandoz, November 2011). No severe AEs occurred, no special concomitant treatments were necessary, and no AE resulted in withdrawal from the study. There were no unexpected AEs in this study. Two serious AEs were reported (appendectomy and constipation), neither of which was considered to be related to study treatment.

\section{Safety profile in post-approval studies and extrapolated indications}

A number of post-approval studies of biosimilar rhGH are ongoing, and these are a useful source of data for this product in indications granted on the basis of extrapolation. The PAtients TReated with Omnitrope ${ }^{\circledR}$ (PATRO) Children study is an ongoing, long-term, post-marketing surveillance

Table I Pivotal phase III studies with Omnitrope ${ }^{\circledR}$

\begin{tabular}{|c|c|c|c|}
\hline Study & AQ study ${ }^{6,7}$ & Lyo study ${ }^{6}$ & Spanish study ${ }^{8}$ \\
\hline Design & $\begin{array}{l}\text { Randomized, controlled, open- } \\
\text { label study (Poland, Hungary) }\end{array}$ & $\begin{array}{l}\text { Open-label, non-comparative } \\
\text { multicenter study (Poland, Hungary) }\end{array}$ & $\begin{array}{l}\text { Open-label, non-comparative } \\
\text { multicenter study (Spain) }\end{array}$ \\
\hline Subjects & $\begin{array}{l}\text { Prepubertal children with GHD, } \\
\text { previously untreated with rhGH }\end{array}$ & $\begin{array}{l}\text { Prepubertal children with GHD, } \\
\text { previously untreated with rhGH }\end{array}$ & $\begin{array}{l}\text { Prepubertal children with GHD, } \\
\text { previously untreated with rhGH }\end{array}$ \\
\hline $\begin{array}{l}\text { Investigational } \\
\text { medicinal products }\end{array}$ & $\begin{array}{l}\text { Omnitrope }{ }^{\circledR} 5 \mathrm{mg} / \mathrm{mL} \text { lyophilized } \\
\text { Omnitrope }^{\circledR} 3.3 \mathrm{mg} / \mathrm{mL} \text { liquid } \\
\text { Reference medicine }\end{array}$ & Omnitrope ${ }^{\circledR} 5 \mathrm{mg} / \mathrm{mL}$ lyophilized & Omnitrope ${ }^{\circledR} 3.3 \mathrm{mg} / \mathrm{mL}$ liquid \\
\hline Dose & $0.03 \mathrm{mg} / \mathrm{kg} \mathrm{SC}$ & $0.03 \mathrm{mg} / \mathrm{kg} \mathrm{SC}$ & $0.03 \mathrm{mg} / \mathrm{kg} \mathrm{SC}$ \\
\hline Duration & Up to 84 months & Up to 48 months & $\begin{array}{l}\text { Up to } 60 \text { months (mean } \\
44 \text { months) }\end{array}$ \\
\hline $\begin{array}{l}\text { Number of } \\
\text { subjects }\end{array}$ & 89 & 51 & 70 \\
\hline
\end{tabular}

Abbreviations: GHD, growth hormone deficiency; rhGH, recombinant human growth hormone; SC, subcutaneous. 
program. ${ }^{10}$ The main objective of PATRO Children is to assess the long-term safety of biosimilar rhGH, particularly in terms of the diabetogenic potential of rhGH therapy, the risk of malignancies, and potential risks of rhGH in children with Prader-Willi syndrome (PWS). All AEs are recorded at each visit for the complete duration of rhGH treatment. Fasting plasma glucose, 2-hour oral glucose tolerance tests, insulin levels, $\mathrm{HbA} 1 \mathrm{c}$, and anti-GH antibodies are requested to be documented according to routine clinical practice.

As of July 2016, 5,007 patients had been enrolled in PATRO Children, with a mean treatment duration of 32.4 months with biosimilar rhGH. ${ }^{11}$ The majority of patients included have GHD; there are also a good number of patients included with a diagnosis of SGA, Turner syndrome (TS), and PWS. Baseline characteristics are shown in Table 2.

Overall, 1,924 patients (38.4\%) had experienced AEs, most of which were mild to moderate in intensity (Table 3 ). Very few patients (3.5\%) had withdrawn due to AEs (Table 4). Omnitrope ${ }^{\circledR}$ treatment was interrupted in 126 patients $(2.5 \%)$ and the dose was reduced in 43 patients $(0.9 \%)$. In total, 284 patients (5.7\%) had reported drug-related AEs, with headache being the most common (75 patients, $1.5 \%$ ) (Table 3). In total, 126 samples from 67 patients were assessed for anti-hGH antibodies. Only one positive antihGH antibody titer occurred transiently in a treatment-naïve patient at baseline; all subsequent results for this patient were negative. So far, 12 patients have been tested for anti-hGH antibodies following 2 years of biosimilar rhGH treatment; no positive anti-hGH antibody titers have been reported in these patients. In addition, there had been no reports of rhGHrelated malignancies or any additional safety concerns.

Also ongoing is a prospective, open-label, non-comparative, multicenter phase IV study to assess the safety and efficacy of Omnitrope ${ }^{\circledR}$ in short children born SGA. ${ }^{12}$ This is the largest prospective clinical study so far conducted on rhGH in SGA patients. In total, 278 children have been enrolled and received study medication; 249 have completed 2 years of treatment. ${ }^{13}$ No child has developed diabetes mellitus during the first 2 years; no fasting glucose or 2-hour oral glucose tolerance test value exceeded the pre-defined limits $(>126$ or $>200 \mathrm{mg} / \mathrm{dL}$, respectively). Treatment-emergent AEs were experienced by $211(76.2 \%)$ children; most of these were mild-to-moderate in intensity (99.3\%) and unrelated to study treatment (97.6\%). Twenty-four drug-related AEs occurred in $17(6.1 \%)$ patients (hypothyroidism, $n=7$; headache, $n=3$; impaired fasting plasma glucose, $n=3$; IGF-I/ IGFBP-3 increased, $\mathrm{n}=2$; thyroid-stimulating hormone increased, $\mathrm{n}=1$; puncture site hematoma, $\mathrm{n}=1$; scoliosis, $\mathrm{n}=1$; upper respiratory tract infection, $\mathrm{n}=1$; bronchitis, $\mathrm{n}=1$;

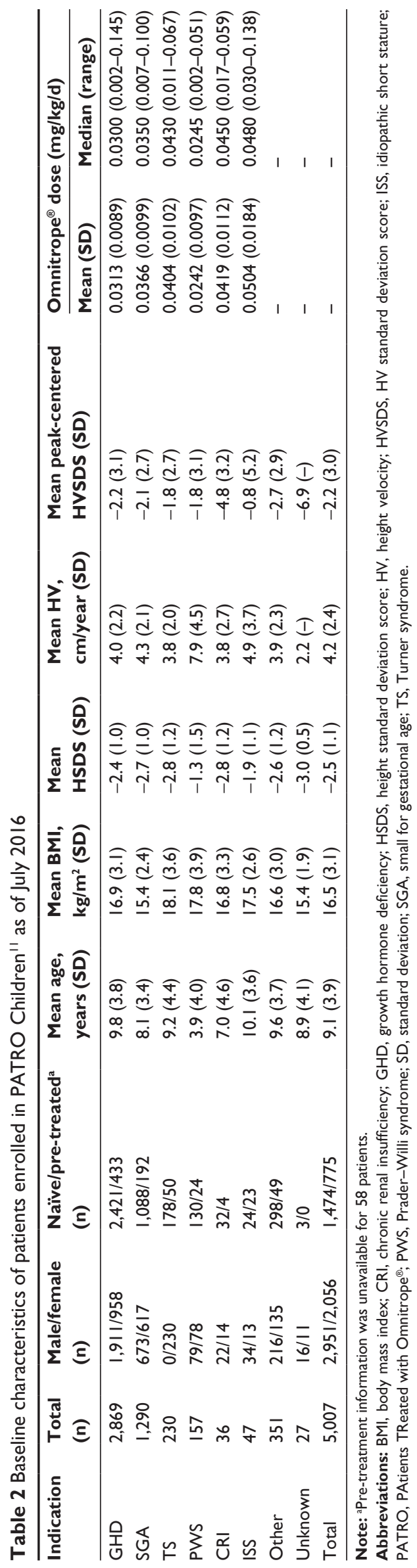


Table 3 Summary of AEs reported in PATRO Children" as of July 2016

\begin{tabular}{|c|c|}
\hline & $\begin{array}{l}\text { Number of subjects (\%) } \\
N=5,007\end{array}$ \\
\hline Any $\mathrm{AE}$ & $1,924(38.4)$ \\
\hline \multicolumn{2}{|l|}{ Relationship to study drug } \\
\hline Not suspected & $1,836(36.7)$ \\
\hline Suspected & $284(5.7)$ \\
\hline \multicolumn{2}{|l|}{ Intensity } \\
\hline Mild & $\mathrm{I}, 48 \mathrm{I}(29.6)$ \\
\hline Moderate & $861(17.2)$ \\
\hline Severe & $186(3.7)$ \\
\hline Missing & $326(6.5)$ \\
\hline \multicolumn{2}{|c|}{ Changes to Omnitrope ${ }^{\circledR}$ treatment } \\
\hline Not changed & $\mathrm{I}, 790(35.7)$ \\
\hline Increased & $66(1.3)$ \\
\hline Reduced & $43(0.9)$ \\
\hline Interrupted & $126(2.5)$ \\
\hline Permanently discontinued & $56(I . I)$ \\
\hline Missing & $93(1.9)$ \\
\hline \multicolumn{2}{|l|}{ Serious AEs } \\
\hline No & $1,832(36.6)$ \\
\hline Yes & $323(6.5)$ \\
\hline \multicolumn{2}{|c|}{ Treatment-related AEs ( $>10$ patients), by } \\
\hline \multicolumn{2}{|l|}{ MedDRA preferred term } \\
\hline Headache & $75(1.5)$ \\
\hline Injection-site hematoma & $19(0.4)$ \\
\hline Arthralgia & $19(0.4)$ \\
\hline Injection-site pain & $18(0.4)$ \\
\hline Hypothyroidism & $13(0.3)$ \\
\hline Pain in extremities & $10(0.2)$ \\
\hline
\end{tabular}

Abbreviations: AE, adverse event; PATRO, PAtients TReated with Omnitrope ${ }^{\circledR}$; MedDRA, Medical Dictionary for Regulatory Activities.

impaired glucose tolerance, $n=1$; pharyngitis, $n=1$; viral infection, $\mathrm{n}=1$; scarlet fever, $\mathrm{n}=1$ ). All were considered mild in severity, except one case of headache, and none required permanent discontinuation of study medication. ${ }^{13}$ Serious AEs were reported in 22 patients $(7.9 \%)$, with only one

Table 4 Reasons for treatment discontinuation in PATRO Children" as of July 2016, n (\%)

\begin{tabular}{ll}
\hline Patient reached final height/bone age maturation & $488(29.8)$ \\
$\mathrm{HV}$ slowdown (HV $<\mathrm{I} \mathrm{cm} /$ year) & $6(0.4)$ \\
Reached near final height & $85(5.2)$ \\
Patient satisfied with current height & $85(5.2)$ \\
Patient does not wish to continue the injections & $176(10.7)$ \\
Patient non-compliant & $5 \mathrm{I}(3.1)$ \\
Non-responder & $78(4.8)$ \\
Adverse event & $57(3.5)$ \\
Switch to other GH product & $113(6.9)$ \\
Lost to follow-up & $199(12.1)$ \\
Other reasons & $276(16.8)$ \\
Unknown & $10(0.6)$ \\
Total & $\mathrm{I}, 640(100)$ \\
\hline
\end{tabular}

Abbreviations: $\mathrm{GH}$, growth hormone; HV, height velocity; PATRO, PAtients TReated with Omnitrope ${ }^{\circledR}$. (severe headache) suspected to be related to study treatment. There have been no reports of malignancies or deaths during the first 2 years of treatment. ${ }^{13}$

PATRO Adults is an ongoing observational, multicenter, open, longitudinal study of biosimilar rhGH, conducted in hospitals and specialized endocrinology clinics across Europe. The primary objective is to assess the safety and efficacy of biosimilar rhGH in adults treated in routine clinical practice. ${ }^{14}$ As of March 2016, 1,043 patients had been enrolled in the study; 562 (54\%) had received previous GH treatment. ${ }^{15}$ To date, 2,025 AEs had been reported in 597 (54\%) patients, with 317 (in 187 patients) regarded as serious. One hundred and sixteen AEs in 72 patients were suspected as drug-related. These included 19 nervous system disorders, 19 musculoskeletal/connective tissue disorders, 17 general disorders/administration site conditions, and two investigations (increased IGF levels). Twenty-two serious AEs in 14 patients were recorded as possibly related to study treatment, including one incidence of diabetes mellitus. Of the 159 patients who had discontinued treatment, 39 did so due to an AE.

\section{Changing to Omnitrope ${ }^{\circledR}$ from other rhGH treatments}

Physicians are often required to change the rhGH used by their patients due to health plan and/or patients' insurance demands,${ }^{16}$ or changes in formularies. It has been suggested that changing patients from one type of rhGH to another may adversely affect patient care. ${ }^{17}$ Several studies have evaluated the impact of changing from other rhGH treatments to biosimilar rhGH. An analysis of phase III clinical data assessed the efficacy and safety of rhGH in children who received continuous biosimilar rhGH therapy either with lyophilized powder for solution or ready-to-use solution, and children who received 9 months of treatment with the reference rhGH followed by biosimilar rhGH solution thereafter. ${ }^{18}$ Across all groups, few children experienced ADRs; more ADRs were observed during the first than the second 9-month treatment period, whether the patients were changed between products or stayed continuously on the same treatment. ${ }^{18}$ Immunogenicity was uncommon across the groups analyzed. No relevant increased risk of anti-GH antibodies emerged following the change from the reference rhGH to biosimilar rhGH. ${ }^{18}$ Another study has reported data from Sweden following the change (for cost reasons) of children ( $\mathrm{n}=98)$ from other rhGHs to biosimilar rhGH. ${ }^{19}$ Following the change to biosimilar rhGH there were no reports of serious or unexpected ADRs. 


\section{Formation of antibodies}

Immunogenicity is a potential concern for all biological medicines. The mechanisms that lead to a break in immune tolerance to recombinant human proteins are not completely understood, but patient- and product-related factors are thought to be involved. ${ }^{20,21}$ Administration of large therapeutic proteins via the subcutaneous route (which results in therapeutic proteins such as rhGH reaching the circulation via the lymphatic system) is more likely to stimulate an immune response than other administration routes. The development of an immune response to a biological therapy may not necessarily have any clinical consequences. Occasionally, however, clinical consequences can arise; if the generated antibodies neutralize the activity of the biopharmaceutical and/or the endogenous protein, loss of efficacy or more serious clinical effects can occur. ${ }^{22}$ The capacity of antibodies to bind to biosimilar rhGH is low, and there is no effect on response to treatment. Testing for antibodies to GH is advised in any patient with an otherwise unexplained lack of response. The incidence of antibody formation to biosimilar rhGH is similar to that reported for the reference medicine. ${ }^{23}$

In the AQ study, some patients who developed anti-rhGH antibodies received a non-commercial lyophilized form of biosimilar rhGH, which included an undetected increased content of host cell proteins. ${ }^{7}$ Once switched to the improved commercial preparation, the proportion of patients with detectable antibodies had decreased after 3 months and continued to do so over the course of the study; the presence of anti-rhGH antibodies did not have any impact on patient growth (Figure 1). Similarly, the safety profile was comparable in patients with and without detectable antibodies. One of 45 patients treated with the reference rhGH over 9 months developed anti-rhGH antibodies. Forty-four of these patients were switched to biosimilar rhGH liquid formulation, three of whom developed low titers of anti-rhGH antibodies; at the final visit ( 84 months) no patient had detectable levels of antibodies. ${ }^{7}$ The immunogenicity profile of biosimilar rhGH in the other pre-approval studies was also reassuring. None of the participants in the Lyo study or the French phase IIIb study developed anti-rhGH antibodies during 24 months treatment. ${ }^{7}$ In the Spanish phase III study, 2 out of 70 patients (2.9\%) treated with biosimilar rhGH for up to 60 months developed anti-rhGH antibodies; in all cases, the occurrence of antibodies was transient in nature. ${ }^{8}$

In the phase IV SGA study, anti-rhGH antibody levels above the cutoff value were measured in 7 patients $(2.7 \%)$ at year 1 and in 3 patients (1.2\%) at year $2 .{ }^{13}$ Positive test results were transient, with only $2(0.8 \%)$ patients having antibodies above the cutoff value on two separate visits.

An analysis was performed of pooled antibody test data across the biosimilar rhGH clinical development program. Data from 4,645 tests in 492 patients were analyzed; included patients had participated in the three phase III studies (including the AQ study), the phase IIIb study conducted in France, and the phase IV study in SGA children. Overall, only $6(1.2 \%)$ patients had antibody titers above the cutoff value on two separate visits, confirming the low immunogenic potential of biosimilar rhGH. None of the patients from these studies discontinued treatment due to increased antibody titers.

\section{Summary}

A substantial data set is available to fully understand the safety profile of biosimilar rhGH, which includes data from its clinical development studies and 10 years of post-approval experience. Based on the available data, there have been
A

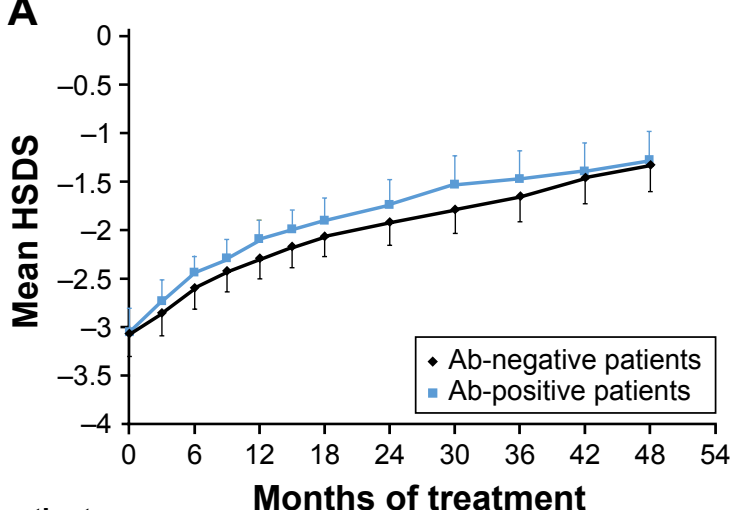

No. of patients

\section{Months of treatment}

Ab-negative $\begin{array}{lllllllll}57 & 55 & 55 & 55 & 51 & 50 & 48 & 45 & 44\end{array}$

Ab-positive $\begin{array}{lllllllll}29 & 30 & 30 & 30 & 29 & 28 & 27 & 26 & 25\end{array}$

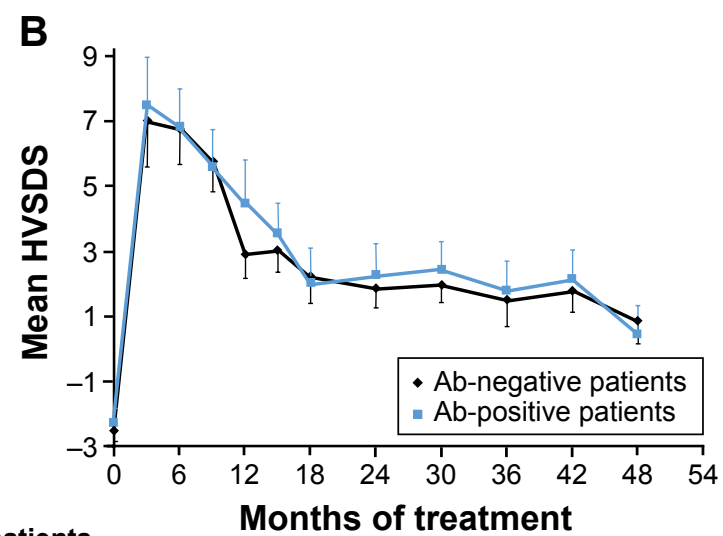

No. of patients

Ab-negative $\begin{array}{llllllllll}59 & 56 & 56 & 55 & 49 & 49 & 46 & 41 & 38\end{array}$

Ab-positive $\begin{array}{lllllllll}30 & 29 & 29 & 29 & 28 & 26 & 24 & 23 & 22\end{array}$

Figure I HSDS (A) and HVSDS (B) among patients in the AQ study (unpublished data April 2009) who did and did not develop anti-rhGH antibodies. Abbreviations: HSDS, height standard deviation score; HVSDS, height velocity standard deviation score; rhGH, recombinant human growth hormone. 
no unexpected or unique AEs related to biosimilar rhGH treatment. There is no increased risk of cancer or adverse glucose homeostasis with biosimilar rhGH compared with the reference medicine and other rhGH products. In addition, the immunogenicity of biosimilar rhGH is similar to that of the reference and other rhGH products.

Extrapolation is an important element of the biosimilar concept and is part of the framework for approval of these agents by the European Medicines Agency; it allows for approval of a biosimilar for the same indications as the reference medicine without the need for clinical studies in each individual condition, as long as the mode of action is the same in the different indications. Post-approval studies are therefore important to provide safety and efficacy data in extrapolated indications. Again, these studies have not uncovered any unexpected or unique safety concerns with biosimilar rhGH, and have not shown any increased risk of AEs associated with specific conditions such as TS (scoliosis, diabetes, slipped capital femoral epiphysis), PWS (scoliosis, obstructive sleep apnea), and short children born SGA (diabetes). Physicians can be reassured that the safety profile of biosimilar rhGH is in keeping with that of other rhGH products.

\section{Acknowledgment}

Medical writing assistance was provided by Tony Reardon of Spirit Medical Communications Ltd, funded by Sandoz GmbH.

\section{Disclosure}

BK has received lecture fees from, and acted as a consultant for, Merck Serono, Novo Nordisk, Pfizer, and Sandoz. MW has been an investigator in Sandoz-sponsored clinical trials. NH and MZ are employees of Sandoz International $\mathrm{GmbH} / \mathrm{Hexal} \mathrm{AG}$. The authors report no other conflicts of interest in this work.

\section{References}

1. Pfäffle R. Hormone replacement therapy in children: the use of growth hormone and IGF-I. Best Pract Res Clin Endocrinol Metab. 2015;29(3): 339-352.

2. Allen DB, Backeljauw P, Bidlingmaier M, et al. GH safety workshop position paper: a critical appraisal of recombinant human GH therapy in children and adults. Eur J Endocrinol. 2016;174(2):P1-P9.

3. Albertsson-Wikland K, Martensson A, Savendahl L, et al. Mortality is not increased in recombinant human growth hormone-treated patients when adjusting for birth characteristics. J Clin Endocrinol Metab. 2016; 101(5):2149-2159.

4. Carel JC, Butler G. Safety of recombinant human growth hormone. Endocr Dev. 2010;18:40-54.

5. Ahangari G, Ostadali MR, Rabani A, Rashidian J, Sanati MH, Zarindast MR. Growth hormone antibodies formation in patients treated with recombinant human growth hormone. Int Jimmunopathol Pharmacol. 2004;17(1):33-38.
6. Romer T, Peter F, Saenger P, et al. Efficacy and safety of a new readyto-use recombinant human growth hormone solution. $J$ Endocrinol Invest. 2007;30(7):578-589.

7. Romer T, Saenger P, Peter F, et al. Seven years of safety and efficacy of the recombinant human growth hormone Omnitrope in the treatment of growth hormone deficient children: results of a phase III study. Horm Res. 2009; 72(6):359-369.

8. López-Siguero J, Borrás Pérez MV, Balser S, Khan-Boluki J. Longterm safety and efficacy of the recombinant human growth hormone Omnitrope ${ }^{\circledR}$ in the treatment of Spanish growth hormone deficient children: results of a phase III study. Adv Ther. 2011;28(10):879-893.

9. Borrás Pérez V, López-Siguero JP, Martínez G, et al. A follow-up study to monitor adult height among Spanish children with growth hormone deficiency who received biosimilar human recombinant growth hormone (Omnitrope ${ }^{\circledR}$ ) during a phase III clinical trial. Adv Ther. 2015; 32(2):148-156.

10. Pfäffle R, Schwab KO, Marginean O, et al. Design of, and first data from, PATRO Children, a multicentre, noninterventional study of the longterm efficacy and safety of Omnitrope ${ }^{\circledR}$ in children requiring growth hormone treatment. Ther Adv Endocrinol Metab. 2013;4(1):3-11.

11. Pfäffle R, Kanumakala S, Höybye C, et al. Four-year results from PATRO Children, a multi-centre, non-interventional study of the longterm safety and efficacy of Omnitrope ${ }^{\circledR}$ in children requiring growth hormone treatment. Poster presented at: 55th Annual Meeting of the European Society for Paediatric Endocrinology; September 10-12; 2016; Paris, France.

12. Schwarz HP, Birkholz-Walerzak D, Szalecki M, et al. One-year data from a long-term phase IV study of recombinant human growth hormone in short children born small for gestational age. Biol Ther. 2014; 4(1-2):1-13.

13. Schwarz HP, Walczak M, Birkholz-Walerzak D, et al. Two-year data from a long-term phase IV study of recombinant human growth hormone in short children born small for gestational age. Adv Ther. 2016; 33(3):423-434.

14. Beck-Peccoz P, Minuto F, Leal-Cerro A, Zabransky M, Stalla G. Rationale and design of PATRO Adults, a multicentre, noninterventional study of the long-term efficacy and safety of Omnitrope ${ }^{\circledR}$ for the treatment of adult patients with growth hormone deficiency. Ther $A d v$ Endocrinol Metab. 2012;3(3):85-91.

15. Beck-Peccoz P, Höybye C, Murray R, et al. Latest results from the PATRO Adults study of Omnitrope ${ }^{\circledR}$ for the treatment of adult patients with growth hormone deficiency. Poster presented: 18th European Congress of Endocrinology; May 28-31; 2016; Munich, Germany.

16. Rashid N, Saenger P, Wu YL, et al. Switching to Omnitrope ${ }^{\circledR}$ from other recombinant human growth hormone therapies: a retrospective study in an integrated healthcare system. Biol Ther. 2014;4(1-2):27-39.

17. Grimberg A, Feudtner C, Gordon CM. Consequences of brand switches during the course of pediatric growth hormone treatment. Endocr Pract. 2012;18(3):307-316.

18. Romer T, Zabransky M, Walczak M, Szalecki M, Balser S. Effect of switching recombinant human growth hormone: comparative analysis of phase 3 clinical data. Biol Ther. 2011;1(1):5.

19. Flodmark CE, Lilja K, Woehling H, Järvholm K. Switching from originator to biosimilar human growth hormone using dialogue teamwork: single-center experience from Sweden. Biol Ther. 2013;3:35-43.

20. Ryff JC, Schellekens H. Immunogenicity of rDNA-derived pharmaceuticals. Trends Pharmacol Sci. 2002;23(6):254-256.

21. Jelkmann W. Biosimilar recombinant human erythropoietins ("epoetins") and future erythropoiesis-stimulating treatments. Expert Opin Biol Ther. 2012;12(5):581-592.

22. Schellekens H. Biosimilar therapeutics - what do we need to consider? NDT Plus. 2009;2(Suppl 1):i27-i36.

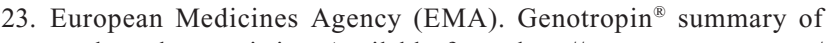
product characteristics. Available from: http://www.ema.europa.eu/ docs/en_GB/document_library/Referrals_document/Genotropin_7_5/ WC500013685.pdf. Accessed July 22, 2016. 


\section{Publish your work in this journal}

Drug Design, Development and Therapy is an international, peerreviewed open-access journal that spans the spectrum of drug design and development through to clinical applications. Clinical outcomes, patient safety, and programs for the development and effective, safe, and sustained use of medicines are the features of the journal, which has also been accepted for indexing on PubMed Central. The manuscript management system is completely online and includes a very quick and fair peer-review system, which is all easy to use. Visit http://www.dovepress.com/testimonials.php to read real quotes from published authors.

Submit your manuscript here: http://www.dovepress.com/drug-design-development-and-therapy-journal 